\title{
Construction and Analytical Application of Internal Amplification Controls (IAC) for Detection of Food Supply Chain-Relevant Viruses by Real-Time PCR-Based Assays
}

\author{
Marta Diez-Valcarce • Katarina Kovač • Nigel Cook • \\ David Rodríguez-Lázaro • Marta Hernández \\ Received: 15 December 2010 / Accepted: 11 February 2011 / Published online: 5 April 2011 \\ (C) The Author(s) 2011. This article is published with open access at Springerlink.com
}

\begin{abstract}
Internal amplification controls (IACs) were constructed for incorporation into real-time nucleic acid amplification assays for bovine polyomavirus, hepatitis A virus, hepatitis $\mathrm{E}$ virus, human adenovirus, human norovirus genogroup I, human norovirus genogroup II, murine norovirus and porcine adenovirus. The addition of optimised amounts of IAC into the assays did not affect the limits of detection for each specific target virus. A poorly performed extraction of viral nucleic acids was simulated, and the effectiveness of IACs in identifying failed assays was demonstrated. The IACs constructed in this study can be reliably used in their specific assays to provide a robust control that can be routinely applied in the analysis of foods for viruses.
\end{abstract}

Keywords Internal amplification control · False negatives . Real-time PCR · Food · Enteric virus

\section{Introduction}

Gastroenteritis produced by ingestion of food contaminated with enteric viruses is an important concern for public health. Thus, detection of the presence of enteric virusesparticularly norovirus, hepatitis $\mathrm{A}$ and $\mathrm{E}$ and adenovirusin foods is an important issue in food safety, and a rapid

\footnotetext{
M. Diez-Valcarce $\cdot$ K. Kovač • D. Rodríguez-Lázaro •

M. Hernández $(\square)$

Instituto Tecnológico Agrario de Castilla y León (ITACyL),

Ctra. Burgos, km.119,

47071 Valladolid, Spain

e-mail: ita-herperma@itacyl.es

N. Cook

Food and Environment Research Agency (FERA),

Sand Hutton,

York, UK
}

and robust diagnostic methodology is needed (Croci et al. 2008; Greening and Hewitt 2008; Cook and Rzezutka 2006). Because at present most of these viruses cannot, or with difficulty, be cultured and integrated cell culture real-time PCR methods are useful but too time-consuming for the quick results required by the food industry, a detection approach based on nucleic acid amplification is necessary (RodríguezLázaro et al. 2007; Bosch et al. 2011). However, the application of nucleic acid amplification to foodstuffs can be complicated by the presence of inhibitory substances (Rodríguez-Lázaro et al. 2004, 2006; Rodríguez-Lázaro and Hernandez 2006), which can cause false negative interpretations of the results. It is imperative therefore for the effective implementation of nucleic acid amplification in food analysis that appropriate controls are used to verify there has been no interference caused by the presence of inhibitory substances (Rodríguez-Lázaro et al. 2007; Bosch et al. 2011). The incorporation of an internal amplification control (IAC) will identify failed reactions (Bosch et al. 2011; Rodríguez-Lázaro et al. 2004, 2007). An IAC is a nontarget nucleic acid sequence present in every reaction which can be co-amplified simultaneously with the target sequence (Cone et al. 1992). In a reaction without an IAC, a negative response can mean either that there is no target sequence present in the reaction or that the amplification has been inhibited. However, with the use of an IAC in each reaction, the absence of response both from the target and the IAC indicates that the reaction has failed, and the sample must be retested to avoid any false negative interpretation of its analysis.

The aim of this study was to construct IACs for nucleic acid amplification assays for viruses relevant to the analysis of foods and to define their analytical application. The viruses were human norovirus genogroups I (NoVGI) and II (NoVGII), hepatitis A virus (HAV) and hepatitis E virus (HEV), murine norovirus (MNV; which could be used to 
assess the efficiency of a pre-nucleic acid amplification sample treatment), human adenovirus (HAdV; which could be used to indicate that routes of virus contamination exist from human sources), porcine adenovirus (PAdV; which could be used to indicate that routes of virus contamination exist from porcine sources) and bovine polyomavirus (BPyV; which could be used to indicate that routes of virus contamination exist from bovine sources).

\section{Materials and Methods}

\section{Viruses and Viral Nucleic Acids}

Bovine polyomavirus DNA and porcine adenovirus DNA were kindly provided by Professor Rosina Gironés of the University of Barcelona, Spain. Hepatitis A virus suspension was kindly provided by Dr. Dario de Medici of the Istituto Superiore de Sanità, Rome, Italy. Hepatitis E virus RNA was kindly provided by Dr. Malcolm Banks of the Veterinary Laboratories Agency, Weybridge, UK. Murine norovirus (MNV1) was supplied by Herbert W. Virgin IV, Washington University School of Medicine (US) and human adenovirus type 2 (HAdV2) was provided by Dr. Rosina Girones at the University of Barcelona (Spain), both viruses were replicated in the Dr. Franco Ruggeri's laboratory at the Istituto Superiore de Sanità (Rome, Italy). MNV1 was propagated in RAW264.7 cells and titrated by end-point dilution (final stock concentration, $10^{7} \mathrm{TCID}_{50} / \mathrm{ml}$ ). HAdV-2 was propagated in A549 cells and titrated by the same technique (final stock concentration, $10^{7} \mathrm{TCID}_{50} / \mathrm{ml}$ ). Human norovirus genogroup I RNA and human norovirus genogroup II RNA were kindly provided by Dr. Ana Maria de Roda Husman of RIVM, Bilthoven, The Netherlands.

\section{Primers and Probes}

The oligonucleotides used in this study are shown in Tables 1 and 2. IAC primers were designed using the software Primer Express $^{\mathrm{TM}}$ version 2.0 (Applied Biosystems, Foster City, CA, USA). All oligonucleotides were purchased from MWG Biotech AG (Ebersberg, Germany), except the minor groove binder (MGB) TaqMan probes HAV150(-), MGB-ORF1/ ORF2 and PrfAP that were acquired from Applied Biosystems (Warrington, UK) and NV1LCpr that was from Sigma-Aldrich (St. Louis, MO, USA).

\section{Bovine Polyomavirus Real-Time PCR}

This assay was a duplex real-time PCR using the primers and conditions described by Hundesa et al. (2010), with the inclusion of an IAC and a carryover contamination prevention system utilising uracil $N$-glycosylase (UNG).
The reaction contained $1 \times$ TaqMan Universal PCR Master Mix (Applied Biosystems, Foster City, CA, USA), $0.4 \mu \mathrm{M}$ each primer, $0.120 \mu \mathrm{M}$ bovine polyomavirus TaqMan probe (labelled with FAM), $50 \mathrm{nM}$ IAC probe (labelled with VIC) and varying copies of bovine polyomavirus IAC. A 10- $\mu$ l sample of nucleic acid extract was added to make a final reaction volume of $25 \mu \mathrm{l}$. The thermocycling conditions were $10 \mathrm{~min}$ at $95{ }^{\circ} \mathrm{C}$, followed by 45 cycles of $15 \mathrm{~s}$ at $95{ }^{\circ} \mathrm{C}$ and $1 \mathrm{~min}$ at $60{ }^{\circ} \mathrm{C}$.

Hepatitis A Virus Reverse Transcription Real-Time PCR

This assay was a one-step duplex reverse transcription realtime PCR using the primers and conditions described by Costafreda et al. (2006), with the inclusion of an IAC. The reaction contained $1 \times$ RNA Ultrasense reaction mix (Invitrogen, Carlsbad, CA, USA), $0.5 \mu \mathrm{M}$ primer HAV68, $0.9 \mu \mathrm{M}$ primer HAV240, $0.25 \mu \mathrm{M}$ probe HAV150(-) (labelled with FAM), $50 \mathrm{nM}$ IAC probe (labelled with VIC), 1× ROX reference dye (Invitrogen), $1 \mu$ RNA Ultrasense enzyme mix (Invitrogen) and varying copies of HAV IAC. A 10- $\mu$ l sample of nucleic acid extract was added to make a final reaction volume of $20 \mu \mathrm{l}$. The thermocycling conditions were $15 \mathrm{~min}$ at $50{ }^{\circ} \mathrm{C}, 2 \mathrm{~min}$ at $95{ }^{\circ} \mathrm{C}$, followed by 45 cycles of $15 \mathrm{~s}$ at $95^{\circ} \mathrm{C}$ and $1 \mathrm{~min}$ at $60^{\circ} \mathrm{C}$.

\section{Hepatitis E Virus Reverse Transcription Real-Time PCR}

This assay was a one-step duplex reverse transcription realtime PCR using the primers and conditions described by Jothikumar et al. (2006), with the inclusion of an IAC. The reaction contained $1 \times$ RNA Ultrasense reaction mix (Invitrogen), $0.25 \mu \mathrm{M}$ each primer, $0.1 \mu \mathrm{M}$ probe HEV-P (labelled with FAM), $50 \mathrm{nM}$ IAC probe (labelled with VIC), $1 \times$ ROX reference dye (Invitrogen), $1 \mu$ l RNA Ultrasense enzyme mix (Invitrogen) and varying copies of HEV IAC. A 10- $\mu 1$ sample of nucleic acid extract was added to make a final reaction volume of $20 \mu$ l. The thermocycling conditions were $15 \mathrm{~min}$ at $50{ }^{\circ} \mathrm{C}, 2 \mathrm{~min}$ at $95^{\circ} \mathrm{C}$, followed by 45 cycles of $10 \mathrm{~s}$ at $95^{\circ} \mathrm{C}, 20 \mathrm{~s}$ at $55^{\circ} \mathrm{C}$ and $15 \mathrm{~s}$ at $72{ }^{\circ} \mathrm{C}$.

\section{Human Adenovirus Real-Time PCR}

This assay was a duplex real-time PCR using the primers and conditions described by Hernroth et al. (2002), with the inclusion of an IAC and a carryover contamination prevention system utilising UNG. The reaction contained $1 \times$ TaqMan Universal PCR Master Mix (Applied Biosystems, Foster City, CA, USA), $0.9 \mu \mathrm{M}$ each primer, $0.225 \mu \mathrm{M}$ adenovirus TaqMan probe (labelled with FAM), $50 \mathrm{nM} \mathrm{IAC}$ probe (labelled with VIC) and varying copies of adenovirus IAC. A $10-\mu l$ sample of nucleic acid extract was added to 
Table 1 Hybrid oligonucleotides designed in this study for the construction of the IACs and probe used for IAC detection

\begin{tabular}{|c|c|c|c|c|}
\hline Target & Name & Type & Sequence $\left(5^{\prime}-3^{\prime}\right)$ & IAC size (bp) \\
\hline BPyV & $\begin{array}{l}\text { QB-F1-1IAC } \\
\text { QB-R1-1IAC }\end{array}$ & $\begin{array}{l}\text { Forward primer } \\
\text { Reverse primer }\end{array}$ & $\frac{\text { CTAGATCCTACCCTCAAGGGAATGGCTCTATTTGCGGTC }}{\text { TTACTTGGATCTGGACACCAACTCTTGATGCCATCAGGA }}$ & 115 \\
\hline HAV & $\begin{array}{l}\text { HAVIACF } \\
\text { HAVIACR }\end{array}$ & $\begin{array}{l}\text { Forward primer } \\
\text { Reverse primer }\end{array}$ & $\begin{array}{l}\text { TCACCGCCGTTTGCCTAGGGCTCTATTTGCGGTC } \\
\text { GGAGAGCCCTGGAAGAAAGTCTTGATGCCATCAGGA }\end{array}$ & 107 \\
\hline $\mathrm{HEV}$ & $\begin{array}{l}\text { HEVIACF } \\
\text { HEVIACR }\end{array}$ & $\begin{array}{l}\text { Forward primer } \\
\text { Reverse primer }\end{array}$ & $\begin{array}{l}\text { GGTGGTTTCTGGGGTGACGGCTCTATTTGCGGTC } \\
\text { AGGGGTTGGTTGGATGAATCTTGATGCCATCAGGA }\end{array}$ & 106 \\
\hline HAdV & $\begin{array}{l}\text { IACAdF } \\
\text { IACAdR }\end{array}$ & $\begin{array}{l}\text { Forward primer } \\
\text { Reverse primer }\end{array}$ & $\begin{array}{l}\text { CWTACATGCACATCKCSGGGGCTCTATTTGCGGTCAACTT } \\
\text { CRCGGGCRAAYTGCACCAGTCTTGATGCCAT }\end{array}$ & 107 \\
\hline NoVGI & $\begin{array}{l}\text { NOR1IACF } \\
\text { NOR1IACR }\end{array}$ & $\begin{array}{l}\text { Forward primer } \\
\text { Reverse primer }\end{array}$ & $\begin{array}{l}\text { CGCTGGATGCGNTTCCATGGCTCTATTTGCGGTC } \\
\text { CCTTAGACGCCATCATCATTTACTCTTGATGCCATCAGGA }\end{array}$ & 111 \\
\hline NoVGII & $\begin{array}{l}\text { NOR2IACF } \\
\text { NOR2IACR }\end{array}$ & $\begin{array}{l}\text { Forward primer } \\
\text { Reverse primer }\end{array}$ & $\begin{array}{l}\text { ATGTTCAGRTGGATGAGRTTCTCWGAGGCTCTATTTGCGGTC } \\
\text { TCGACGCCATCTTCATTCACATCTTGATGCCATCAGGA }\end{array}$ & 117 \\
\hline MNV1 & $\begin{array}{l}\text { IACMuNvF } \\
\text { IACMuNvR }\end{array}$ & $\begin{array}{l}\text { Forward primer } \\
\text { Reverse primer }\end{array}$ & $\begin{array}{l}\text { CACGCCACCGATCTGTTCTGGGCTCTATTTGCGGT } \\
\text { GCGCTGCGCCATCACTCTCTTGATGCCATCAG }\end{array}$ & 107 \\
\hline PAdV & $\begin{array}{l}\text { IACPAdF } \\
\text { IACPAdR }\end{array}$ & $\begin{array}{l}\text { Forward primer } \\
\text { Reverse primer }\end{array}$ & $\begin{array}{l}\overline{\text { AACGGCCGCTACTGCAAGGGCTCTATTTGCGGTC }} \\
\text { AGCAGCAGGCTCTTGAGGTCTTGATGCCATCAGGAG }\end{array}$ & 105 \\
\hline L. monocytogenes & PrfAP & Probe & $\overline{\text { VIC-CCATACACATAGGTCAGG-MGBNFQ }}$ & \\
\hline
\end{tabular}

The sequences shown in bold are identical in each forward or reverse primer and correspond to a fragment of the L. monocytogenes prfA gene. Sequences underlined are identical to the specific primers for each target virus. Bases within the degenerated primers correspond to $\mathrm{W}=\mathrm{A}$ or $\mathrm{T} ; \mathrm{Y}=\mathrm{C}$ or $\mathrm{T} ; \mathrm{K}=\mathrm{G}$ or $\mathrm{T} ; \mathrm{R}=\mathrm{A}$ or $\mathrm{G} ; \mathrm{S}=\mathrm{C}$ or $\mathrm{G}$ and $\mathrm{N}=\mathrm{A}, \mathrm{T}, \mathrm{C}$ or $\mathrm{G}$

make a final reaction volume of $25 \mu$. The thermocycling conditions were $10 \mathrm{~min}$ at $95^{\circ} \mathrm{C}$, followed by 45 cycles of $15 \mathrm{~s}$ at $95^{\circ} \mathrm{C}$ and $1 \mathrm{~min}$ at $60^{\circ} \mathrm{C}$.

\section{Human Norovirus ggI Reverse Transcription Real-Time} PCR

This assay was a one-step duplex reverse transcription realtime PCR using the primers and conditions described by Svraka et al. (2007), with the inclusion of an IAC. The reaction contained $1 \times$ RNA Ultrasense reaction mix (Invitrogen), $0.5 \mu \mathrm{M}$ primer QNIF4, $0.9 \mu \mathrm{M}$ primer NV1LCR, $0.25 \mu \mathrm{M}$ probe NV1LCpr (labelled with FAM), $50 \mathrm{nM}$ IAC probe (labelled with VIC), $1 \times$ ROX reference dye (Invitrogen), $1 \mu l$ RNA Ultrasense enzyme mix (Invitrogen) and varying copies of norovirus ggI IAC. A 10- $\mu$ l sample of nucleic acid extract was added to make a final reaction volume of $20 \mu \mathrm{l}$. The thermocycling conditions were $15 \mathrm{~min}$ at $50{ }^{\circ} \mathrm{C}, 2 \mathrm{~min}$ at $95^{\circ} \mathrm{C}$, followed by 45 cycles of $15 \mathrm{~s}$ at $95{ }^{\circ} \mathrm{C}$ and $1 \mathrm{~min}$ at $60{ }^{\circ} \mathrm{C}$.

Human Norovirus ggII Reverse Transcription Real-Time PCR

This assay was a one-step duplex reverse transcription realtime PCR using the primers and conditions described by da Silva et al. (2007), with the inclusion of an IAC. The reaction contained $1 \times$ RNA Ultrasense reaction mix (Invitrogen), $0.5 \mu \mathrm{M}$ primer QNIF2, $0.9 \mu \mathrm{M}$ primer
COG2R, $0.25 \mu \mathrm{M}$ probe QNIFS (labelled with FAM), $50 \mathrm{nM}$ IAC probe (labelled with VIC), $1 \times$ ROX reference dye (Invitrogen), $1 \mu$ l RNA Ultrasense enzyme mix (Invitrogen) and varying copies of norovirus ggII IAC. A 10- $\mu$ l sample of nucleic acid extract was added to make a final reaction volume of $20 \mu \mathrm{l}$. The thermocycling conditions were $15 \mathrm{~min}$ at $50^{\circ} \mathrm{C}, 2 \mathrm{~min}$ at $95^{\circ} \mathrm{C}$, followed by 45 cycles of $15 \mathrm{~s}$ at $95^{\circ} \mathrm{C}$ and $1 \mathrm{~min}$ at $60^{\circ} \mathrm{C}$.

\section{Murine Norovirus Reverse Transcription Real-Time PCR}

This assay was a one-step duplex reverse transcription real-time PCR using the primers and conditions described by Baert et al. (2008), with the inclusion of an IAC. The reaction contained $1 \times$ RNA Ultrasense reaction mix (Invitrogen), $0.2 \mu \mathrm{M}$ each primer, $0.2 \mu \mathrm{M}$ probe MGB-ORF1/ORF2 (labelled with FAM), $50 \mathrm{nM}$ IAC probe (labelled with VIC), $1 \times$ ROX reference dye (Invitrogen), $1 \mu$ l RNA Ultrasense enzyme mix (Invitrogen) and varying copies of murine norovirus IAC. A $10-\mu$ sample of nucleic acid extract was added to make a final reaction volume of $20 \mu$ l. The thermocycling conditions were $15 \mathrm{~min}$ at $50{ }^{\circ} \mathrm{C}, 2 \mathrm{~min}$ at $95{ }^{\circ} \mathrm{C}$, followed by 40 cycles of $15 \mathrm{~s}$ at $95{ }^{\circ} \mathrm{C}$ and $1 \mathrm{~min}$ at $60^{\circ} \mathrm{C}$.

Porcine Adenovirus Real-Time PCR

This assay was a duplex real-time PCR using the primers and conditions described by Hundesa et al. (2009), with the inclusion of an IAC and a carryover contamination 
Table 2 Oligonucleotides used in this study to detect target viruses by real-time or RT real-time-PCR

\begin{tabular}{|c|c|c|c|c|c|}
\hline Target & Name & Type & Sequence $\left(5^{\prime}-3^{\prime}\right)$ & $\begin{array}{l}\text { Amplicon } \\
\text { size (bp) }\end{array}$ & Reference \\
\hline \multirow[t]{3}{*}{ BPyV } & QB-F1-1 & Forward primer & СТАGATCСТАСССТСАAGGGAAT & \multirow[t]{3}{*}{77} & \multirow[t]{3}{*}{ Hundesa et al. (2010) } \\
\hline & QB-R1-1 & Reverse primer & TTACTTGGATCTGGACACCAAC & & \\
\hline & QB-P1-2 & Probe & 6FAM-GACAAAGATGGTGTGTATCCTGTTGA -BHQ & & \\
\hline \multirow[t]{3}{*}{ HAV } & HAV68 & Forward primer & TCACCGCCGTTTGCCTAG & \multirow[t]{3}{*}{173} & \multirow[t]{3}{*}{ Costafreda et al. (2006) } \\
\hline & HAV 240 & Reverse primer & GGAGAGCCCTGGAAGAAAG & & \\
\hline & HAV150(-) & Probe & 6FAM-CCTGAACCTGCAGGAATTAA-MGBNFQ & & \\
\hline \multirow[t]{3}{*}{ HEV } & JVHEVF & Forward primer & GGTGGTTTCTGGGGTGAC & \multirow[t]{3}{*}{70} & \multirow[t]{3}{*}{ Jothikumar et al. (2006) } \\
\hline & JVHEVR & Reverse primer & AGGGGTTGGTTGGATGAA & & \\
\hline & JVHEVP & Probe & 6FAM-TGATTCTCAGCCCTTCGC-BHQ & & \\
\hline \multirow[t]{3}{*}{ HAdV } & $\mathrm{AdF}$ & Forward primer & CWTACATGCACATCKCSGG & \multirow[t]{3}{*}{69} & \multirow[t]{3}{*}{ Hernroth et al. (2002) } \\
\hline & AdR & Reverse primer & CRCGGGCRAAYTGCACCAG & & \\
\hline & AdP1 & Probe & 6FAM-CCGGGCTCAGGTACTCCGAGGCGTCCT-BHQ & & \\
\hline \multirow[t]{3}{*}{ NoVGI } & QNIF4 & Forward primer & CGCTGGATGCGNTTCCAT & \multirow[t]{3}{*}{86} & \multirow[t]{3}{*}{ Svraka et al. (2007) } \\
\hline & NV1LCR & Reverse primer & CCTTAGACGCCATCATCATTTAC & & \\
\hline & NV1LCpr & Probe & 6FAM-TGGACAGGAGAYCGCRATCT-BHQ & & \\
\hline \multirow[t]{3}{*}{ NoVGII } & QNIF2d & Forward primer & ATGTTCAGRTGGATGAGRTTCTCWGA & \multirow[t]{3}{*}{89} & \multirow[t]{3}{*}{ da Silva et al. (2007) } \\
\hline & COG2R & Reverse primer & TCGACGCCATCTTCATTCACA & & \\
\hline & QNIFS & Probe & 6FAM-AGCACGTGGGAGGGCGATCG-BHQ & & \\
\hline \multirow[t]{3}{*}{ MNV1 } & Fw-ORF1/ORF2 & Forward primer & CACGCCACCGATCTGTTCTG & \multirow[t]{3}{*}{109} & \multirow[t]{3}{*}{ Baert et al. (2008) } \\
\hline & Rv-ORF1/ORF2 & Reverse primer & GCGCTGCGCCATCACTC & & \\
\hline & MGB-ORF1/ORF2 & Probe & 6FAM-CGCTTTGGAACAATG-MGB-NFQ & & \\
\hline \multirow[t]{3}{*}{ PAdV } & Q-PAdV-F & Forward primer & AACGGCCGCTACTGCAAG & \multirow[t]{3}{*}{68} & \multirow[t]{3}{*}{ Hundesa et al. (2009) } \\
\hline & Q-PAdV-R & Reverse primer & AGCAGCAGGCTCTTGAGG & & \\
\hline & Q-PAdV-P & Probe & 6FAM-CACATCCAGGTGCCGC-BHQ & & \\
\hline
\end{tabular}

Probes were labelled with 6FAM at the $5^{\prime}$ end and MGB-NFQ or BHQ at the $3^{\prime}$ end

6FAM 6-carboxyfluorescein, $M G B-N F Q$ minor groove binder non-fluorescent quencher, $B H Q$ black hole quencher

prevention system utilising UNG. The reaction contained $1 \times$ TaqMan Universal PCR Master Mix (Applied Biosystems, Foster City, CA, USA), $0.9 \mu \mathrm{M}$ each primer, $0.225 \mu \mathrm{M}$ porcine adenovirus TaqMan probe (labelled with FAM), $50 \mathrm{nM}$ IAC probe (labelled with VIC) and varying copies of porcine adenovirus IAC. A 10- $\mu$ l sample of nucleic acid extract was added to make a final reaction volume of $25 \mu \mathrm{l}$. The thermocycling conditions were $10 \mathrm{~min}$ at $95{ }^{\circ} \mathrm{C}$, followed by 45 cycles of $15 \mathrm{~s}$ at $95{ }^{\circ} \mathrm{C}$, $20 \mathrm{~s}$ at $55^{\circ} \mathrm{C}$ and $20 \mathrm{~s}$ at $60^{\circ} \mathrm{C}$.

\section{IAC Construction}

The principles for the construction of IACs can be explained in two different phases: First, PCR amplification of non-target DNA is performed using hybrid oligonucleotide primers. This produces a chimeric DNA molecule containing non-target sequences flanked by target sequences complementary to the virus-specific primers. This molecule is then cloned into a plasmid. If the IAC is for RNA virus detection, the plasmid should contain a T7 RNA polymerase promoter, and IAC RNA transcripts are subse- quently produced by T7 RNA polymerase. The plasmid or the RNA transcript is the chimeric IAC which is co-amplified with the virus primers and detected using a fluorescent probe complementary to the internal non-target sequence (Fig. 1). When using a real-time PCR-based assay, the virus target amplicons are detected with specific hydrolysis probes, labelled with one fluorophore (e.g. FAM), and the IAC amplicons are detected with the specific IAC probe, labelled with a different fluorophore (e.g. VIC).

Each IAC in this study was designed as a DNA or RNA molecule containing sequences from the prfA gene from Listeria monocytogenes (nucleotide positions 2281-2348, AN AY512499) flanked by the sequences complementary to the primers used in the specific assays. With the exception of the prfA sequence, the IAC sequences did not show significant similarity to any other sequence deposited in public databases, as shown by BLAST-N searches (National Center for Biotechnology Information, Bethesda, MD, USA; www.ncbi.nlm.nih.gov). The chimeric DNA molecules were generated by PCR as previously described (Rodríguez-Lázaro et al. 2004, 2005) using as template $5 \mathrm{ng}$ of L. monocytogenes strain CECT 935 DNA and the 
specific set of construction hybrid primers for each IAC (Table 1), which contained the corresponding prfA target sequence plus a $5^{\prime}$ tail with the virus forward/reverse primer sequences. The PCR products were excised from a $2 \% 1 \times$ TBE agarose gel and purified using QIAquick Gel Extraction Kit (Qiagen, Hilden, Germany), then cloned into the pCR 2.1-TOPO Vector (Invitrogen) in the case of IACs for the HAV, HEV and NoVGII assays or into the pGEM-T Easy Vector (Promega, Madison, WI, USA) in the case of IACs for the NoVGI, BPyV, HAdV, PAdV and MNV1 assays. The concentration and quality of the plasmid DNA stock solutions were determined by fluorimetry using Quant-iT PicoGreen dsDNA reagents (Invitrogen) in a NanoDrop 3300 Fluorospectrometer (Thermo Fisher Scientific, Wilmington, DE, USA).

\section{Production of IAC RNA}

In vitro transcription was performed to obtain RNA fragments for the HAV, HEV, NoVGI, NoVGII and MNV1 IACs using the Riboprobe System-T7 (Promega). To prevent carryover contamination by DNA, RNA was treated with DNase (RQ1 RNase-free DNase, Promega) at a concentration of $1 \mathrm{U} / \mathrm{\mu g}$ for $15 \mathrm{~min}$ at $37{ }^{\circ} \mathrm{C}$, then purified using an RNeasy Mini Kit (Qiagen) according to the manufacturer's recommendations. The concentration and purity of the RNA stock solutions were determined by fluorimetry using Quant-iT RiboGreen RNA and Quant-iT PicoGreen dsDNA reagents (Invitrogen) in a NanoDrop 3300 Fluorospectrometer (Thermo Fisher Scientific).

\section{Copy Number Calculation}

The number of IAC copies was calculated by dividing the amount of IAC in each stock solution by the weight of one IAC molecule, as follows:

DNA IAC copies $=\mathrm{g}$ in the IAC stock /

$$
\begin{aligned}
& \left(\mathrm{bp} \times 660 \mathrm{DA} / \mathrm{bp} \times 1.6 \times 10^{-27} \mathrm{~kg} / \mathrm{DA}\right. \\
& \left.\times 1 \times 10^{-3} \mathrm{~g} / \mathrm{kg}\right)
\end{aligned}
$$

RNA IAC copies $=\mathrm{g}$ in the IAC stock /

$$
\begin{aligned}
& \left(\mathrm{bp} \times 320 \mathrm{DA} / \mathrm{bp} \times 1.6 \times 10^{-27} \mathrm{~kg} / \mathrm{DA}\right. \\
& \left.\times 1 \times 10^{-3} \mathrm{~g} / \mathrm{kg}\right)
\end{aligned}
$$

Optimization of IAC-Containing Nucleic Acid

Amplification Assays

After construction and copy number calculation of the IACs, the following steps were performed, in this particular order:

1. Verification that the IAC could be amplified and detected in a uniplex assay
2. Verification that the IAC and the template could be simultaneously amplified and detected in the same reaction tube, i.e. a duplex assay

3. Optimization of the IAC probe concentration by performing (reverse transcription) real-time PCRs without virus nucleic acids but containing 3,000 IAC copies (or 2,000 IAC copies for RNA virus methods), $100 \mathrm{nM}$ of virus target probe and increasing amounts of the IAC probe $(25,50$ and $100 \mathrm{nM})$

4. Determination of the optimal amount of IAC. First, each assay's target consistent limit of detection (LOD) was determined in the absence of an IAC by establishing the lowest number of genome equivalents (GE) that could be detected in every one of five replicate reactions. Then, decreasing numbers of IACs (down to approximately one copy) were added, and the lowest IAC number which could be consistently detected in five replicate reactions without affecting the LOD of the target was established

Demonstration of IAC Applicability in the Detection of Viruses in Food

To demonstrate the effectiveness of the IAC approach, a foodstuff artificially contaminated with two virus types was analysed. Strawberry puree $(25 \mathrm{~g})$ was placed into a sterile plastic bag. Approximately $10^{6} \mathrm{TCID}_{50}$ of human adenovirus and $10^{6} \mathrm{TCID}_{50}$ of murine norovirus were added to the puree. The sample was then processed using the method of Dubois et al. (2006). Approximately $25 \mathrm{~g}$ fruit was placed in a sterile beaker. Forty millilitres of Tris-glycine, $\mathrm{pH} 9.5$, buffer containing $1 \%$ beef extract and 6,500 U pectinase (Pectinex $^{\mathrm{TM}}$ Ultra SPL Solution, Sigma) was added to the sample, which was then agitated at room temperature for $20 \mathrm{~min}$ by rocking at $60 \mathrm{rpm}$. The $\mathrm{pH}$ was maintained at 9.0 throughout (if necessary adjusting using $4 \%$ $(w / v)$ sodium hydroxide, extending the period of agitation by 10 min each time an adjustment was made. In strongly coloured berries, a change in colour of the eluate from blue/purple to red was considered indicative of acidification and was used to trigger $\mathrm{pH}$ adjustment). The liquid was decanted from the beaker through a strainer (e.g. a tea strainer) into one $50-\mathrm{ml}$ or two smaller centrifuge tubes and centrifuged at $10,000 \times \mathrm{g}$ for $30 \mathrm{~min}$ at $4{ }^{\circ} \mathrm{C}$. The supernatant(s) was decanted into a single clean tube or bottle and the $\mathrm{pH}$ adjusted to 7.2. Volumes $(0.25)$ of $50 \%(w / v)$ polyethylene glycol $8000 / 1.5 \mathrm{M}$ $\mathrm{NaCl}$ were then added and mixed by shaking for $1 \mathrm{~min}$. The suspension was then incubated with gentle rocking at $4{ }^{\circ} \mathrm{C}$ for $60 \mathrm{~min}$ before centrifugation at $10,000 \times \mathrm{g}$ for $30 \mathrm{~min}$ at $4{ }^{\circ} \mathrm{C}$. The supernatant was discarded and the 
Fig. 1 IAC construction

\section{Detection target \\ Virus DNA/RNA}

IAC target
L. monocytoge

L. monocytogenes DNA

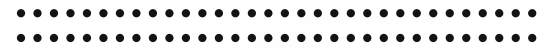

Primer L.monoF

$\bullet \bullet \bullet$

.............................

$\ldots \ldots \ldots \ldots \ldots \ldots \ldots \ldots \ldots \ldots \ldots \ldots$

$\bullet \cdots$

Primer L.monoR

Primer IACF

Primer IACF

….............

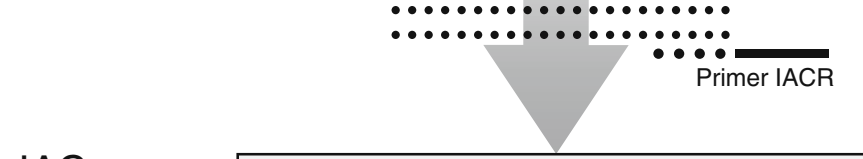

$1^{\text {st }}$ PCR

$2^{\text {nd }}$ PCR

IAC
Chimeric DNA

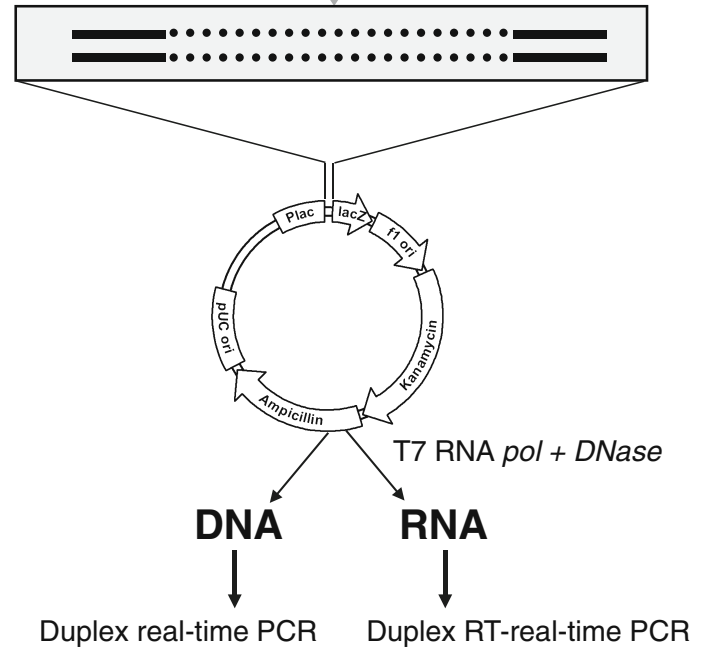

pellet compacted by centrifugation at $10,000 \times g$ for $5 \mathrm{~min}$ at $4{ }^{\circ} \mathrm{C}$ before resuspension in $500 \mu \mathrm{l}$ phosphate-buffered saline. The suspension was then transferred to a chloroform-resistant tube, and $500 \mu \mathrm{l}$ chloroform/butanol (1:1) was added and mixed by vortexing. The sample was allowed to stand for $5 \mathrm{~min}$ and then centrifuged at $10,000 \times \mathrm{g}$ for $15 \mathrm{~min}$ at $4{ }^{\circ} \mathrm{C}$. The aqueous phase was transferred to a clean tube and immediately used for nucleic acid extraction or stored at $-20{ }^{\circ} \mathrm{C}$. Nucleic acids were extracted using a NucliSENS miniMAG kit (bioMérieux, Marcy l'Etoile, France) according to the manufacturer's instructions. The final elutions were performed with $150 \mu$ l elution buffer, resulting in a $300-\mu 1$ nucleic acid extract. The nucleic acid extract was assayed immediately or stored at $-70{ }^{\circ} \mathrm{C}$.

To demonstrate how the IACs would indicate reaction failure, a situation in which nucleic acid purification had been poorly performed was modelled by adding $50 \mu \mathrm{l}$ of non-extracted strawberry puree to $50 \mu \mathrm{l}$ nucleic acid extract prior to nucleic acid amplification.

\section{Results}

Optimization of the IAC Probe Concentration

For each virus detection method, several experiments were performed as detailed in "Materials and Methods" in duplex (IAC and target probes) and uniplex (IAC probe) formats, and the best performance concentration chosen was that which showed the lowest $C_{\mathrm{p}}$ value with less difference between the duplex and uniplex formats and having the most similar value within the five replicates (Table 3). The results indicated that a probe concentration of $50 \mathrm{nM}$ in all assays exhibits enough fluorescence intensity and that the assay performance in duplex and uniplex was satisfactory.

Determination of the Optimal Amount of IAC for Each Assay

After optimization of IAC amount per reaction as detailed in "Materials and Methods", the target LOD for each virus 
was recalculated; norovirus GGI had 100 GE per reaction, and the LOD for all other target viruses was $10 \mathrm{GE}$ (Table 4). These LODs were established in the amount of virus GE when the target signal was present in all five replicates, and if just one target signal was not present in all replicates, the results were not considered robust enough. It is remarkable that the LOD of the HEV system was established at $10 \mathrm{GE}$ when $C_{\mathrm{p}}$ values were as high as $41.50 \pm 1.80$ whilst at 100 GE were $33.56 \pm 0.61$ (data not shown), indicating consistency of the results.

Demonstration of IAC Applicability in the Detection of Viruses in Food

The results from the analysis of the purified and inhibitorcontaining nucleic acid extracts from the artificially contaminated strawberry puree are shown in Table 5. A signal was obtained for both target viruses and their IACs from the assay of the purified extract. No target virus or IAC signal was obtained from the assay of the inhibitorcontaining extract.

\section{Discussion}

If monitoring of food supply chains for viruses is to be effectively performed as part of a food safety programme (Rodríguez-Lázaro et al. 2007), then it is vitally necessary that the reliability of the analytical results can be verified. Many matrices from the food supply chains which are most prone to virus contamination - salad vegetable, shellfish and soft fruit - contain substances which can inhibit nucleic acid amplification; therefore, it is essential that this verification includes the recognition of failed assays as these may mask the presence of a virus pathogen by a false negative interpretation of the results (Hoorfar et al. 2004). The use of an amplification control can provide this recognition.

There are two approaches to the use of amplification controls. The first is to run two separate reactions for each sample: One (the test) reaction contains only the sample nucleic acid, but the other (the control reaction) contains the sample nucleic acid plus the amplification control (Costafreda et al. 2006). The latter is thus termed an external amplification control (EAC). If it is successfully amplified to produce a signal, any non-production of a target signal in the test reaction is considered to signify that the sample was uncontaminated. If, however, no signal is produced in both the test and control reactions, it signifies that the nucleic acid extract contains inhibitory substances and the reaction has failed.

In contrast to an EAC, an IAC is a non-target DNA sequence present in the very same reaction as the sample nucleic acid extract (Hoorfar et al. 2004). If it is successfully amplified to produce a signal, any non-

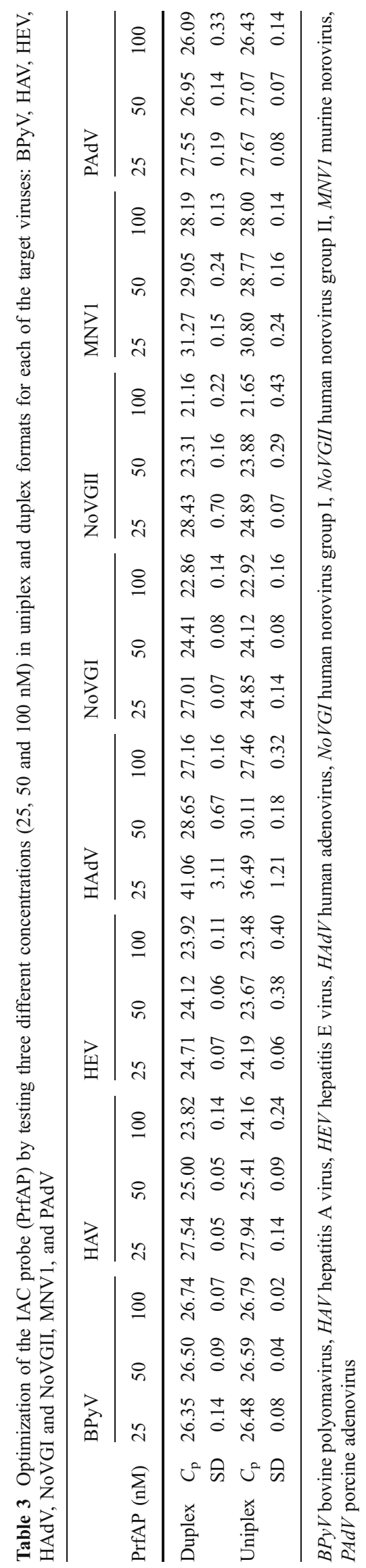


Table 4 Limits of detection of BPyV, HAV, HEV, HAdV, NoVGI and NoVGII, MNV1 and PAdV assays and optimal number of IAC copies for each assay

\begin{tabular}{lllllllll}
\hline & BPyV & HAV & HEV & HAdV & NoVGI & NoVGII & MNV1 & PAdV \\
\hline LOD & 10 & 10 & 10 & 10 & 100 & 10 & 10 & 10 \\
$C_{\mathrm{p}} \pm \mathrm{SD}$ & $36.37 \pm 0.59$ & $26.28 \pm 0.61$ & $41.50 \pm 1.80$ & $34.62 \pm 0.60$ & $29.78 \pm 0.21$ & $27.54 \pm 0.09$ & $38.74 \pm 0.56$ & $36.54 \pm 0.56$ \\
IAC & 300 & 300 & 300 & 100 & 300 & 300 & 600 & 100 \\
$C_{\mathrm{p}} \pm \mathrm{SD}$ & $28.79 \pm 0.06$ & $30.29 \pm 0.31$ & $35.48 \pm 0.36$ & $33.69 \pm 0.25$ & $28.38 \pm 0.10$ & $32.65 \pm 0.03$ & $36.07 \pm 0.44$ & $34.66 \pm 0.10$
\end{tabular}

BPyV bovine polyomavirus, $H A V$ hepatitis A virus, HEV hepatitis E virus, HAdV human adenovirus, NoVGI human norovirus group I, NoVGII human norovirus group II, $M N V 1$ murine norovirus, $P A d V$ porcine adenovirus, $L O D$ limit of detection of the specific target virus

production of a target signal in the reaction is considered to signify that the sample was uncontaminated. If, however, the reaction produces neither a signal from the target nor the IAC, it signifies that the reaction has failed.

Optimally, since using different primer sets may cause the amplification control to react to an inhibitory substance differently to the target, it should possess the same primer sequences as the target: This is the "competitive" strategy (Hoorfar et al. 2004). It is so called because the amplification control can compete with the target for the primers. This potential competition issue has led some workers to adopt the EAC approach, but this does contain a degree of ambiguity because one can never be completely certain that the test reaction has not individually failed, for example, through pipetting error or non-homogeneous contamination by inhibitory substances. For example, if an EAC signal is produced in the control reaction but no target signal is produced in the test reaction, one cannot be completely certain that the test reaction has not failed. Using an IAC eliminates this ambiguity since it is present in the mastermix and a signal will always appear when the reaction has not failed or high levels of competing target are not present (if they are, a target signal will be produced anyway).

The concern of the proponents of the EAC approach regards the possibility that a low level of target may be outcompeted by the IAC, leading to a false negative result.
However, a thoroughly optimised assay should not present these problems (D’Agostino et al. 2004; Rodríguez-Lázaro et al. 2010). In the current study, the amount of IAC incorporated in each assay was thoroughly optimised to ensure that it did not interfere with the analytical sensitivity of the assay. The limit of detection of the target of each assay remains the same.

Nonetheless, the IAC must be present in the reaction in sufficient quantity to perform its function, and it can only do that reliably if it consistently shows a signal in the absence of a target or in the presence of low target concentrations. The IACs developed in this study all had this capacity.

Finally, it should be demonstrated that an amplification control can identify failed reactions. In this study, using strawberries, which have been implicated in several outbreaks of viral disease (Food and Agriculture Organization of the United Nations/World Health Organization 2008) and which have often been found to contain inhibitory substances (Croci et al. 2008), the IACs showed that the performance of assays for both RNA and DNA viruses could be verified.

In conclusion, this study has produced a suite of IACs for nucleic acid amplification assays suitable for use in the analysis of food supply chain samples for viruses. The IACs constructed in this study can be reliably used in their specific assays and thus provide a robust control that can be routinely applied in the analysis of foods for viruses.

Table 5 Detection of viruses in purified and inhibitor-containing nucleic acid extracts of strawberry puree artificially contaminated with human adenovirus and murine norovirus

\begin{tabular}{|c|c|c|c|c|c|}
\hline & \multicolumn{2}{|c|}{ Human adenovirus } & \multicolumn{2}{|c|}{ Murine norovirus } & \multirow[t]{2}{*}{ Interpretation } \\
\hline & Target & IAC & Target & IAC & \\
\hline Purified extract & $\begin{array}{l}20.88 \pm 0.15^{\mathrm{b}} \\
(9 / 9)^{\mathrm{c}}\end{array}$ & $\begin{array}{l}33.52 \pm 0.30 \\
(9 / 9)\end{array}$ & $\begin{array}{l}35.05 \pm 0.35 \\
(9 / 9)\end{array}$ & $\begin{array}{l}37.04 \pm 0.69 \\
(9 / 9)\end{array}$ & Positive \\
\hline Inhibitor-containing extract ${ }^{\mathrm{a}}$ & $\begin{array}{l}\text { Undet. } \\
(0 / 9)\end{array}$ & $\begin{array}{l}\text { Undet. } \\
(0 / 9)\end{array}$ & $\begin{array}{l}\text { Undet. } \\
(0 / 9)\end{array}$ & $\begin{array}{l}\text { Undet. } \\
(0 / 9)\end{array}$ & False negative \\
\hline
\end{tabular}

\footnotetext{
${ }^{a}$ Non-extracted strawberry puree suspension $(50 \mu \mathrm{l})$ added to $50 \mu \mathrm{l}$ of nucleic acid extracted from artificially contaminated strawberry puree

${ }^{\mathrm{b}}$ Mean and standard deviation of $C_{\mathrm{p}}$ values of three independent nucleic acid amplification reactions using three replicates in each

${ }^{\mathrm{c}}$ Positive reactions out of nine reactions
} 
Acknowledgements This work was supported by the EU VITAL project contract no. 213178. M.D.-V. received a Ph.D. studentship from the Instituto Nacional de Investigación y Tecnología Agraria y Alimentaria (INIA). N.C. acknowledges the support of the United Kingdom Food Standards Agency.

Open Access This article is distributed under the terms of the Creative Commons Attribution Noncommercial License which permits any noncommercial use, distribution, and reproduction in any medium, provided the original author(s) and source are credited.

\section{References}

Baert L, Wobus CE, Van Coillie E, Thackray LB, Debevere J, Uyttendaele M (2008) Appl Environ Microbiol 74:543

Bosch A, Sánchez G, Abbaszadegan M, Carducci A, Guix S, Le Guyader FS, Netshikweta R, Pinto R, van der Poel WHM, Rutjes S, Sano D, Taylor MB, van Zyl WB, Rodríguez-Lázaro D, Kovač K, Sellwood J (2011) Food Anal Methods 4:4

Cone RW, Hobson AC, Huang ML (1992) J Clin Microbiol 30:3185, Erratum in: J Clin Microbiol 32:2633 (1994)

Cook N, Rzezutka A (2006) Hepatitis viruses. In: Motarjemi Y, Adams M (eds) Emerging foodborne pathogens. Woodhead, Cambridge, pp 282-308

Costafreda MI, Bosch A, Pintó RM (2006) Appl Environ Microbiol $72: 3846$

Croci L, Dubois E, Cook N, de Medici D, Schultz AC, China B, Rutjes S, Hoorfar J, van der Poel WHM (2008) Food Anal Methods 1:73

da Silva AK, Le Saux JC, Parnaudeau S, Pommepuy M, Elimelech M, Le Guyader FS (2007) Appl Environ Microbiol 73:7891

D'Agostino M, Wagner M, Vazquez-Boland JA, Kuchta T, Karpiskova R, Hoorfar J, Novella S, Scortti M, Ellison J, Murray A, Heuvelink A, Kuhn M, Pazlarova J, Fernandez I, Cook N (2004) J Food Prot 67:1646
Dubois E, Hennechart C, Deboosère N, Merle G, Legeay O, Burger C, Le Calvé M, Lombard B, Ferré V, Traoré O (2006) Int J Food Microbiol 108:164

Food and Agriculture Organization of the United Nations/World Health Organization (2008) Microbiological risk assessment series, no. 13

Greening GE, Hewitt J (2008) Food Anal Methods 1:109

Hernroth BE, Conden-Hansson AC, Rehnstam-Holm AS, Girones R, Allard AK (2002) Appl Environ Microbiol 68:4523

Hoorfar J, Malorny B, Abdulmawjood A, Cook N, Wagner M, Fach P (2004) J Clin Microbiol 42:1863

Hundesa A, Maluquer de Motes C, Albinana-Gimenez N, RodriguezManzano J, Bofill-Mas S, Suñen E, Girones R (2009) J Virol Methods 158:130

Hundesa A, Bofill-Mas S, Maluquer de Motes C, RodriguezManzano J, Bach A, Casas M, Girones R (2010) J Virol Methods 163:385

Jothikumar N, Cromeans TL, Robertson BH, Meng XJ, Hill VR (2006) J Virol Methods 131:65

Rodríguez-Lázaro D, Hernandez M (2006) J Rapid Methods Autom Microbiol 14:395

Rodríguez-Lázaro D, D’Agostino M, Pla M, Cook N (2004) J Clin Microbiol 42:5832

Rodríguez-Lázaro D, Pla M, Scortti M, Monzó HJ, Vázquez-Boland JA (2005) Appl Environ Microbiol 71:9008

Rodríguez-Lázaro D, Lewis DA, Ocampo-Sosa AA, Fogarty U, Makrai L, Navas J, Scortti M, Hernandez M, Vazquez-Boland JA (2006) Appl Environ Microbiol 72:4256

Rodríguez-Lázaro D, Lombard B, Smith H, Rzezutka A, D'Agostino M, Helmuth R, Schroeter A, Malorny B, Miko A, Guerra B, Davison J, Kobilinsky A, Hernández M, Bertheau Y, Cook N (2007) Trends Food Sci Techn 18:306

Rodríguez-Lázaro D, López-Enríquez L, Hernandez M (2010) J Appl Microbiol 109:863

Svraka S, Duizer E, Vennema H, de Bruin E, van der Veer B, Dorresteijn B, Koopmans M (2007) J Clin Microbiol 45:1389 